\title{
A scientific note on the detection of American strains of acute paralysis virus and Kashmir bee virus in dead bees in one US honey bee (Apis mellifera L) colony
}

\author{
ACF Hung 1, BV Ball 2, JR Adams 3, H Shimanuki 1, DA Knox ${ }^{1}$ \\ 1 Bee Research Laboratory, USDA, ARS, Beltsville; \\ 2 IACR-Rothamsted Experimental Station, Harpenden, Hentfordshire, AL5 2JQ, UK; \\ 3 Insect Biocontrol Laboratory, USDA, ARS, Beltsville, MD 20705, USA
}

(Received 5 January 1994; accepted 13 December 1995)

Acute paralysis virus (APV) of honey bees was originally discovered as a laboratory phenomenon during work on chronic paralysis virus. It occurs commonly as an inapparent infection of bees in Britain, but has never there been associated with disease or mortality in nature. By contrast, APV has been found as a cause of both adult bee and brood mortality in colonies in mainland Europe infested with the parasitic mite Varroa jacobsoni; APV was also found in the mite itself. Large amounts of APV have also been detected in dead adult bees from colonies infested with $V$ jacobsoni in Florida.

Kashmir bee virus (KBV) was first isolated from diseased adultes of Apis cerana. Strains of KBV have been found in Apis mellifera in Australia and New Zealand, Fiji, Canada and Spain. Three strains of KBV were also found in adult bees collected in the US, but the virus was present only as an inapparent infection and was not reported to cause mortality.

In October 1994 we found one honey bee colony in Maryland (BRL-9), infested with $V$ jacobsoni, which had many bees crawling at the hive entrance, unable to fly. These crawling bees eventually died within $3 \mathrm{~m}$ of the hive. An antiserum with reciprocal titers of 128 against the British APV isolate and 32 against a Canadian strain of KBV was used to test for virus in these dead bees. Double immunodiffusion tests of individual bees showed spur formation of precipitin lines between samples, indicating two serologically distinguishable viruses in the bees. In immunodiffusion tests five individual bees gave strong positive reactions to 
the APV-(British)-type strain antiserum, sixteen individuals gave strong positive reactions to an antiserum to the Canadian strain of $\mathrm{KBV}$, and nine individuals did not react to either antiserum. The individual bees that reacted with the antiserum to the Canadian KBV did not react with the APV antiserum and vice versa. There was therefore no detectable mixed infection of these two viruses in a single bee. This is the first time that a strain of KBV has been found in dead honey bees in the US and the first report of both APV and KBV occurring in the same honey bee colony.

Apis mellifera / acute paralysis virus / Kashmir bee virus / American strain

Note scientifique sur la détection de souches américaines du virus de la paralysie aiguë et du virus Cachemire de l'abeille chez des abeilles mortes dans une colonie d'abeilles (Apis mellifera $L$ ) aux États-Unis

Eine wissenschaftliche Notiz zur Entdeckung amerikanischer Linien des AkutenBienen-Paralyse-Virus und des Kashmir-Bienen-Virus in toten Bienen in einem Bienenvolk in den USA 